\title{
Белорусская газета «Наша Нива» об основании университета в западных губерниях в начале $\mathrm{XX}$ века
}

\author{
Шимукович С.Ф. \\ Государственное учреждение образования «Республиканский институт высшей школы», \\ Беларусь, 220007, г. Минск, ул. Московская, 15 \\ E-mail: 28.05.74@mail.ru
}

\begin{abstract}
Аннотация. В статье анализируются информационные сообщения в газете «Наша Нива», освещающие деятельность вокруг открытия высшего учебного заведения на белорусских землях в начале XX в. Контент-анализ материалов позволяет выявить количественные и качественные показатели развития полемики о высшей школе в крае за годы издания газеты. Интерес представляет используемая белорусскими деятелями аргументация о наиболее приемлемом формате учреждения образования, выборе места расположения вуза и других аспектах развития высшего образования в крае. Выявлены фазы активности региональных элит в деле открытия вуза в западных губерниях. Отмечается, что отсутствие инфраструктуры высшего образования отрицательно сказалось на социально-экономическом развитии белорусских земель и негативно отразилось на динамике продвижения белорусского национального проекта. Одновременно автор отмечает, что правительство блокировало инициативы по открытию вузов во всех городах империи, так как в целом опасалось расширения протестных настроений в академической среде.
\end{abstract}

Ключевые слова: белорусские земли, высшая школа, высшее образование, белорусский университет, белорусская интеллигенция, А. Власов, контент-анализ.

Для цитирования: Шимукович С.Ф. 2021. Белорусская газета «Наша Нива» об основании университета в западных губерниях в начале XX века. Via in tempore. История Политология. 48 (3): 681-693. DOI 10.52575/2687-0967-2021-48-3-681-693.

\section{Belarusian newspaper «Nasha Niva» about the foundation of the university in the Western provinces at the beginning of the 20th century}

\author{
Serguej F. Shymukovich \\ National Institute for Higher Education, \\ 15 Moskovskaya St., Minsk, 220007, Belarus \\ E-mail: 28.05.74@mail.ru
}

\begin{abstract}
The article analyzes the information messages in the newspaper «Nasha Niva», covering the activities around the opening of a higher educational institution in the Belarusian lands at the beginning of the $20^{\text {th }}$ century. The content analysis of the materials allows us to identify quantitative and qualitative indicators of the development of the controversy about higher education in the region over the years of the newspaper's publication. The argument used by Belarusian figures about the most acceptable format of an educational institution, the choice of the location of the university and other aspects of the development of higher education in the region is considered. The phases of activity of regional elites in the opening of a university in the western provinces are revealed. It is noted that the lack of higher education infrastructure has negatively affected the socio-economic development of the Belarusian lands and negatively affected the dynamics of the promotion of the Belarusian national project. At the same time, the author notes that the government blocked initiatives to open universities in all cities of the empire, as it was generally afraid of the expansion of protest moods in the academic environment.
\end{abstract}


Keywords: Belarusian lands, higher school, higher education, Belarusian university, Belarusian intellectuals, A. Vlasov, content analysis.

For citation: Shymukovich S.F. 2021. Belarusian newspaper «Nasha Niva» about the foundation of the university in the Western provinces at the beginning of the 20th century. Via in tempore. History and political science. 48 (3): 681-693 (in Russian). DOI 10.52575/2687-0967-2021-48-3-681-693.

\section{Введение}

Бурные темпы социально-экономической модернизации и развитие гражданских институтов в Российской империи в целом и ее западных губерниях в частности достаточно остро обозначили проблему нехватки квалифицированных кадров как для реального сектора экономики, так и для правительственных и общественных институтов. Естественной реакцией общества было требование расширения системы высшего образования, которая на тот момент не обеспечивала социальный заказ. По подсчетам современных российских исследователей, к началу ХХ в. в России было 9 университетов и около 60 специализированных высших учебных заведений, в том числе 14 частных вузов [Колчинский и др., 2018, с. 44, 63]. При этом в обширнейшем Западном крае высших учебных заведений не было вообще, в то время как на соседних территориях, в том числе в национальных окраинах империи, были представлены самые разнообразные вузы. Так, университеты были в обеих столицах России (Петербурге и Москве), в Харькове, Одессе и Киеве (основан в 1835 г. взамен закрытого Виленского университета) [Шимукович, 2020, с. 128]. Технологические, политехнические, ветеринарные и иные институты действовали в Варшаве, Риге, Харькове, Киеве, Нежине (Черниговская губ.), Ново-Александрии (Люблинская губ.) - их относительная близость к белорусским землям способствовала привлечению учащихся из западных губерний, однако расходы на обучение за пределами края были выше, чем у местных студентов.

В начале XX в. определенную динамику получил белорусский национальный проект. Газета «Наша Нива», которая издавалась на белорусском языке с 1906 г., была единственным рупором белорусских национальных деятелей. На ее страницах публиковались материалы, которые носили для белорусского движения программный характер. Роль «Нашей Нивы» в развитии белорусского национального движения исследовал А.В. Унучек [Унучак, 2008]. Еще один белорусский историк В.А. Пилецкий изучал материалы газеты, в которых с позиций интересов белорусского национального движения озвучивались задачи развития начальной и средней школ по обучению белорусов в начале XX в. [Пілецкі, 2007]. Однако именно инфраструктура высшего образования являлась фактором, способствовавшим эффективности, последовательности и результативности реализации любого национального проекта, что отметил в своем исследовании историк и этнограф П.В. Терешкович. Он сравнил массовость и степень интенсивности украинского и белорусского национального движения и пришел к выводу, что наличие университетов на украинских землях сыграло определяющую роль в большей успешности украинского национального проекта в начале XX в. [Терешкович, 2004, с. 195]. В этой связи актуальным представляется изучение вопроса о видении белорусскими деятелями перспектив развития инфраструктуры высшего образования в Западном крае, о целях высшего образования и задачах национальной интеллигенции как продукта системы высшего образования.

Представители региональных элит с самого начала XX в. предпринимали значительные усилия по организации вуза в Западном крае. Так, на съезде в Вильно представителей сельскохозяйственных обществ в августе 1901 г. рассматривался вопрос о необходимости открытия политехнического института с сельскохозяйственным, лесным, химическим, механическим и строительным отделениями, а на съезде землевладельцев края в Двинске в 1903 г. с обстоятельным докладом о необходимости открытия в крае универси- 
тета с сельскохозяйственным отделением выступил П. Стрельцов [Пічэта, с. 218]. При этом он ссылался на германский опыт и отмечал, что наиболее эффективно сельскохозяйственные науки развиваются и преподаются именно в университетах, а не в специализированных институтах [ Стрельцов, 1903, с. 10-30; Пічэта, 2014, с. 218]. Однако специалисты придерживались иного мнения, так, директор Горыгорецкого земледельческого училища Н.М. Арнольд был сторонником специализированных сельскохозяйственных институтов. Единственное, он не видел перспектив для восстановления сельскохозяйственного вуза в Горках Могилевской губернии в силу «...захолустного положения Горок и отдаленности их от железнодорожных путей, что никоим образом устроено быть не может» ${ }^{148}$.

Активное обсуждение вопроса об открытии вуза в крае на страницах региональных газет способствовало появлению такого нового явления, как конкуренция крупнейших городов края за право принять высшее учебное заведение на своей территории. Вопрос о необходимости учреждения вуза в начале столетия периодически поднимался и на заседаниях Витебской, Минской и Виленской городских дум, где создавались специальные комиссии, которые выявляли преимущества соответствующих локаций и занимались изысканием средств. Никто из экспертов не высказывался о национальном характере университета, он скорее рассматривался как инструмент российского влияния в крае. Тем не менее правительство положительного ответа на местные инициативы не давало [Пічэта, 2014 , c. 222].

К началу XX в. университеты и иные вузы стали серьезными центрами оппозиции правительству. Академическое сообщество оказалось непосредственно вовлечено в политическую борьбу, что особенно ярко проявилось в ходе революции 1905-1907 гг. Хотя профессура и разделилась в вопросе участия в активной политической деятельности, значительное число авторитетных ученых, особенно с либеральными взглядами, все же отказывали режиму в способности обеспечить устойчивое общественное развитие. В это время расхождение правительства со студентами и вовсе достигло критического уровня [Колчинский и др., 2018, с. 46, 51]. Именно эти обстоятельства и стали причиной того, что многочисленные инициативы по открытию новых университетов, поступавшие в правительство из разных губернских городов империи, оставались без одобрения. Как отмечает А.Е. Иванов, 99 \% ходатайств об открытии вузов отвергалось [Иванов, 1991, с. 189]. Правительство достаточно осторожно давало согласие только на создание новых политехнических и медицинских институтов, готовивших кадры для критически важных для государства сфер и отраслей [Колчинский и др., 2018, с. 63].

\section{Объект и методы исследования}

С ноября 1906 г. в Западном крае (в Вильно) начала издаваться газета «Наша Нива», которая занималась продвижением белорусского национального проекта и своей целью видела содействие формированию белорусской модерной нации. Как отмечали издатели в статье-передовице от 7 (20) июля 1911 г., «...вывести наш народ на простую дорогу может та интеллигенция, которая вышла из народа, которую взрастила деревня своими соками, своей кровью и потом. Это - обязанность народной интеллигенции, это - долг, который лежит на ее совести и должен быть возвращен. Только крепко сомкнувшись со своим народом, только работая для развития его культуры, наша сельская интеллигенция вернет этот долг и скинет с себя ответственность за ту темноту, беду, недолю, которая сковала мощными путами белорусскую землицу» [Наша Ніва, 1911, № 27, с. 338]. По мнению издателей и авторов газеты, содействовать появлению белорусской интеллигенции может только университет, основанный в белорусском регионе и белорусский по сво-

${ }^{148}$ Национальный исторический архив Беларуси (далее НИАБ). Ф. 2260. Оп. 1. Д. 296. Л. 1 об., 5. 
ему духу. Эта мысль последовательно продвигалась в ряде редакционных статей и информационных заметок на протяжении 1908-1915 гг.

Для анализа информационных материалов «Нашей Нивы» был применен метод контент-анализа, который позволил выявить и проследить количественные и качественные изменения в подаче информации об учреждении в крае вуза, объективно и системно описать процесс коммуникации вокруг данной проблемы, крайне важной для всех групп региональных элит, на основе чего были сформулированы определенные выводы. Данная методика показала хорошую эффективность при анализе разнообразных материалов СМИ [Семёнова, Корсунская, 2010, с. 9-27].

\section{Результаты и их обсуждение}

В процессе подготовки данной статьи были проанализированы все выпуски газеты «Наша Нива», начиная с первого номера, вышедшего 10 ноября 1906 г. ${ }^{149}$, и по № 31 за 7 августа 1915 г., на котором издание газеты прервалось до 1920 г. Были выявлены информационные материалы, освещающие разные стороны высшего образования: функционирование системы в целом в мире и в России в частности, студенческая жизнь во всех ее проявлениях; сообщения, связанные с открытием и деятельностью разных учреждений высшего образования; формы проявления общественной активности российской профессуры (в том числе уроженцев белорусских земель), представлявшие интерес для издателей «Нашей Нивы». В 1906 г. было выпущено всего 7 номеров газеты. В них присутствует только одно информационное сообщение, посвященное забастовке студентов Московского университета [Наша Ніва, 1906, № 6, с. 6]. В этой связи логично объединить выпуски 1906 и 1907 гг. в одну хронологическую группу. Сведения о количестве информационных материалов, посвященных высшему образованию, по годам издания газеты приведены на рисунке 1.

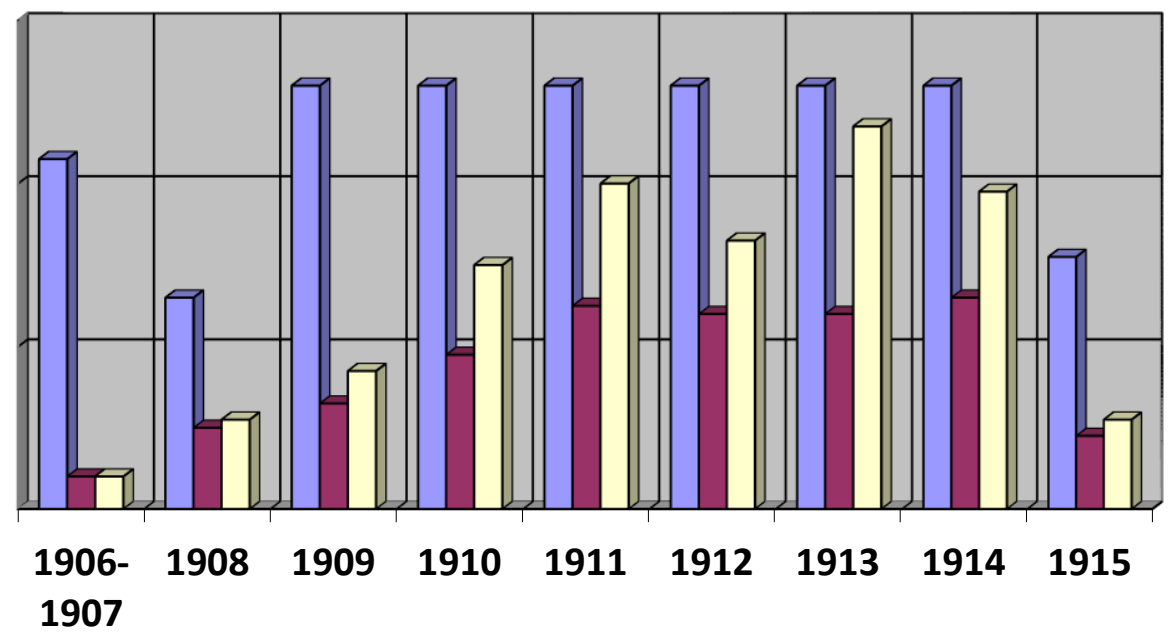

\section{$\square$ Всего вышло номеров газеты "Наша Нива" за год}

Всего выпусков с информационными сообщениями о высшем образовании

\section{$\square$ Всего информационных сообщений о высшем образовании}

Рис. 1. Соотношение числа выпусков газеты «Наша Нива» и информационных материалов о высшем образовании [Наша Ніва, 1906-1915]

Fig. 1. The ratio of the number of issues of the newspaper «Nasha Niva» and information materials about higher education [Nasha Niva, 1906-1915]

149 Используется датировка по старому стилю. 
Итак, можно отметить, что вплоть до 1911 г. постепенно росло количество сообщений о разных аспектах высшего образования. С 1911 по 1914 г. примерно в каждом втором выпуске газеты присутствовал один либо несколько интересующих нас информационных материалов. Серьезные коррективы в приоритеты информационной политики «Нашей Нивы» внесла Первая мировая война. Проблемы высшего образования отошли на второй план, а если и рассматривались, то в контексте призывной кампании для студентов и новых условий функционирования для вузов. Количество информационных сообщений по проблемам высшего образования в выпусках 1915 г. резко сокращается, а с августа издание газеты и вовсе прерывается.

Информационные сообщения о функционировании учреждений высшего образования и студенческой активности (их было больше всего) размещались в рубрике «Со всех сторон», информация об общественной активности в деле основания вуза в крае приводилась в рубрике «Из Беларуси и Литвы» и в нескольких заглавных статьях. Более обстоятельно были подготовлены аналитические материалы, в которых автор (в основном это был издатель газеты А. Власов) рассматривал преимущества тех либо иных видов вузов, приводил аргументы в пользу открытия университета в Вильно.

Активное обсуждение проблемы, связанной с отсутствием вуза в крае, началось с 1908 г., когда в течение года (в апреле, июне и декабре) «Наша Нива» опубликовала три достаточно пространные редакторские статьи, в которых освещались мероприятия местной общественности по созданию вуза, приводились аргументы в пользу открытия университета и констатировался отрицательный результат данной активности с указанием причин неудачи. Так, в первой статье, которая вышла в № 9 от 25 апреля, автор отмечал, что 21 апреля в Вильно состоялось собрание представителей белорусских и литовских городов с редакторами виленских газет и иными заинтересованными в открытии вуза лицами. По мнению автора статьи (а это был редактор-издатель А. Власов), необходимо добиваться открытия университета в Вильно, так как этот крупнейший город является сердцем всего края и имеет удобное транспортное сообщение с другими городами. Автор отмечал недостатки политехнического института, который многие предлагали как альтернативу университету: в нем будет учиться меньше студентов, а выпускники, чаще всего невостребованные на месте в силу неразвитости промышленности, будут уезжать в другие регионы империи. В то же время в крае нужны врачи, учителя, юристы, особенно с учетом перспектив учреждения земств. Университет должен был стать центром региональных исследований: «...работать над языком тех наций, которые у нас живут, изучить хорошо их жизнь, их порядки, да и сам край» [Наша Ніва, 1908, № 9, с. 4]. Приводился в статье и экономический аргумент - затраты студентов на обучение были бы значительно ниже, соответственно, возможность получить университетское образование появилась бы и у крестьянских детей. В статье отмечалось, что Государственная Дума как раз рассматривала проект закона о праве поступать в университеты для выпускников учительских институтов, в которых обучались преимущественно дети крестьян [Наша Ніва, 1908, № 9, с. 4].

Важность доступности высшего образования для всех социальных групп белорусов подчеркивал П.В. Терешкович: «...доля украинцев среди юристов вдвое превышала аналогичный показатель среди белорусов. <...> численность крестьян с университетским образованием в Украине была в 20 раз больше, чем в Беларуси» [Терешкович, 2004, с. 195]. В этой связи украинский национальный проект имел большую поддержку среди населения.

Вторая статья, опубликованная 6 июня, содержит выдержку из выступления редактора газеты А. Власова в комиссии городской думы Вильно, учрежденной для разработки проекта открытия вуза. Основные аргументы автора, а их в статье восемь, сосредоточены вокруг пользы университета для региональных исследований и белорусского и литовского языкознания. По замечанию автора, совершенно не изучены языки местных народов, осо- 
бенно белорусский, который, по мнению филолога-слависта, профессора П.А. Бессонова, самый древний и изначальный, по мнению Е.Ф. Карского - наиболее чистый из славянских [Наша Ніва, 1908, № 12, с. 5]. Мало изучена также история края, особенно «польсколитовские века», в то же время в Виленском центральном архиве древних актов и книг находится огромное количество документов, «написанных белорусским языком», но нет ученых, которые бы их изучали. В самом конце А. Власов отмечает и утилитарную функцию университета - он будет готовить учителей для местных школ и гимназий [Наша Ніва, 1908, № 12, с. 5]. В этой статье, как и в выступлении на заседании комиссии, университет рассматривался в первую очередь как институция, выполняющая региональный социальный заказ и работающая на развитие местных национальных проектов, тогда как во все предшествующие годы вуз в западных губерниях рассматривался исключительно как проводник российского общественного влияния и центр русского просвещения в регионе (именно так говорилось в докладе П.П. Стрельцова) [Пічэта, 2014, с. 220].

Вероятно, что национальный взгляд на университет редактора «Нашей Нивы» и ряда других общественных деятелей, прежде всего литовских, побудили правые российские организации Вильно резко высказаться против идеи учреждения любого высшего учебного заведения в крае. В редакторской статье от 4 декабря, посвященной вопросам русско-польского соперничества в Западном крае, А. Власов с сожалением констатировал, что «...обрусительный “Окраинный союз” начал стараться, чтобы университет не открывали, так как поднимется польский “мятеж”. Приехал “окраинный” депутат, известный уже всем Замысловский, и порадовал нас: “Точно скажу вам, что университета в Вильно не будет!" От такой новости противно стало всем, кто хочет добра этому краю, и бросили заниматься делом об университете» [Наша Ніва, 1908, № 12, с. 5].

Стоит отметить, что личность депутата Государственной Думы от Виленской губернии Г.Г. Замысловского представляет значительный интерес в контексте рассмотрения вопросов развития высшего образования в Российской империи в период между российскими революциями. Во-первых, Георгий Георгиевич был сыном Егора Замысловского, известного профессора-историка, уроженца г. Гродно, преподававшего до 1890 г. в Петербургском университете (умер в 1896 г.) [Стогов, 2019, с. 125]. В этой связи он как сын профессора многие проблемы высшей школы мог оценивать не просто как обыватель, а как человек, близкий к системе образования. Его выступления в Государственной Думе по проблемам высшей школы в 1910-1911 гг. насыщены фактурой и изобилуют оценками, крайне неприятными как для функционеров из правительства, так и для тогдашней профессуры. Как отмечает современный российский исследователь Д.И. Стогов, Г.Г. Замысловский «...считался стратегом и «мозгом» фракции правых в Думе и главным посредником между правительством, думскими и внедумскими представителями правых» [Стогов, 2019, c. 126].

В своих ярких выступлениях депутат образно называл высшую школу тех лет «...революционной ретортой, где из человека наивного, не думающего о политике, господа Гессены и Гредескулы будут готовить революционеров, готовить то пушечное мясо, благодаря которому господа кадеты пробираются к власти» [Замысловский, 2013, с. 282]. В этой связи Г.Г.Замысловский поддерживал правительство в его политике удушения протестов в высшей школе: «...те шаги, которые предприняты теперь правительством, показывают, что оно начинает бороться с революционным засильем студенчества и кадетской профессуры, $<\ldots>$ оно должно главное свое воздействие обратить не на студентов, а на профессуру, должно вырвать высшие учебные заведения от этой сплоченной кадетской группы, которая там засела и которая превращает высшую школу в арену, где эта профессура наживается, пропагандирует, ничего не делает, а государство губит и подготовляет не слуг Родине, а пушечное мясо революции» [Замысловский, 2013, с. 314]. 
В данном контексте становится более понятной резко отрицательная позиция этого человека в отношении учреждения университета в родном для него Западном крае. Она была обусловлена не только тем обстоятельством, что университет может подпасть под влияние местных польских элит, сколько нежеланием усиливать революционные настроения на окраинах империи.

Следует сказать, что периоды общественной активности в деле учреждения вуза в западных губерниях имели волнообразную тенденцию: неудача охлаждала инициаторов на год-два до следующей попытки (рис. 2). Так, вслед за неудачей, постигшей региональные элиты в 1908 г., последовал спад в 1909 и 1910 гг., когда информационных материалов о проектах открытия вуза в крае было минимум, а в 1910 г. они и вовсе отсутствовали, зато в этом же году газета широко освещала мероприятия по открытию вузов, альтернативных государственной форме высшего образования, в других городах империи.

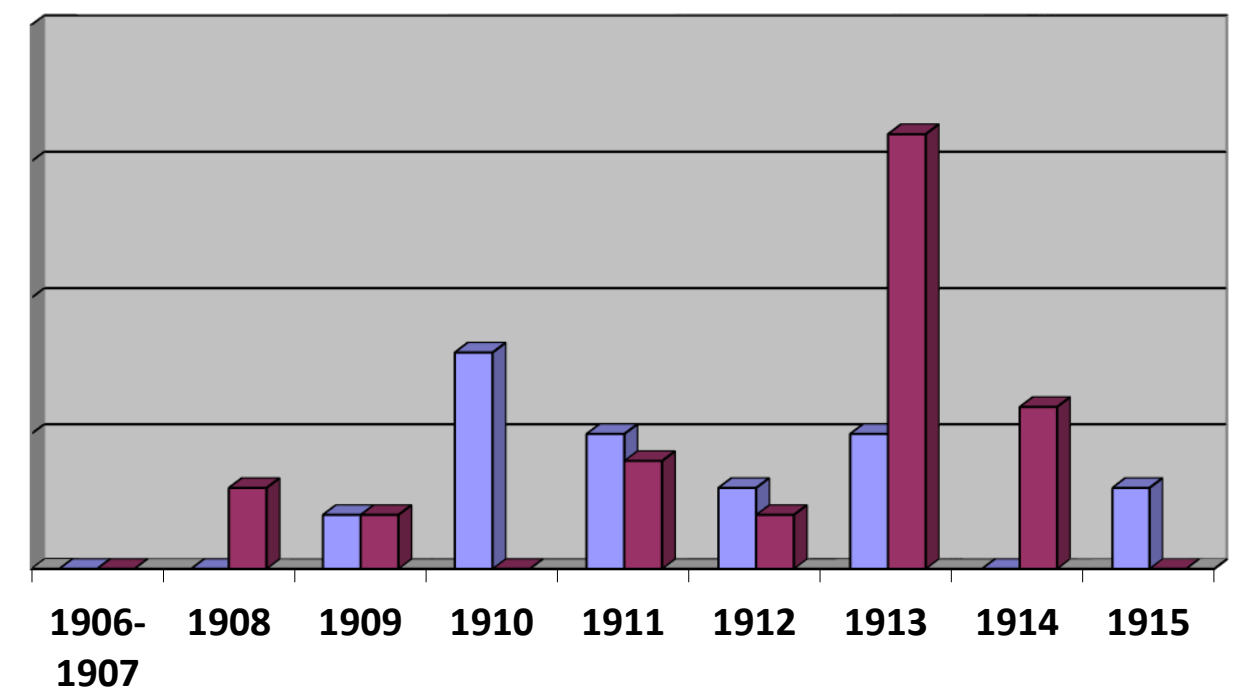

口Иформационные сообщения о деятельности вузов вне западных губ.

口 Информационные сообщения об открытии вузов в западных губ.

Рис. 2. Количество информационных материалов в газете «Наша Нива» о деятельности вузов в мире и об открытии вузов в западных губерниях [Наша Ніва, 1906-1915]

Fig. 2. The number of information materials in the newspaper «Nasha Niva» about the activities of universities in the world and about the opening of a university in the western provinces

[Nasha Niva, 1906-1915]

Так, два сообщения в 1909 г. констатировали неудачу предшествовавшей попытки основать вуз в западных губерниях. При этом вновь упоминался депутат Г.Г. Замысловский как основной враг высшего образования в крае, а также описывался успешный проект по основанию университета в Саратове. Он был учрежден постановлением Государственной Думы, которое утвердил Государственный Совет. В статье-передовице, посвященной работе российского парламента, редактор отмечал: «...Мы, белорусы, видимо, еще не скоро дождемся своего университета в Вильно, который очень нужен для жизни нашего края. Теперь делом о Виленском университете никто не занимается. Была комиссия об этом при Виленской городской думе, но ее "отцы” города втихаря закрыли, наверное, разным “истинным" университет не нравится...» [Наша Ніва, 1909, № 24, с. 353].

В два «кризисных» года - 1909 и 1910 - газета размещала материалы об альтернативных формах получения высшего образования и о проектах учреждения вузов (удачных и неудачных) в других городах империи. Так, в 1909 г. вышли две большие статьи о рабо- 
те так называемых «народных университетов» за границей (№ 18 и 44). Авторы материалов акцентировали внимание на том, что в них могли получать образование беднейшие слои населения, и, как правило, основание народного университета являлось результатом общественной либо частной инициативы.

Газета уделяла внимание основанию и деятельности как государственных, так и частных вузов в России. В 1910 г. «Наша Нива» писала о праздновании в Саратове по поводу открытия университета (№ 2), о желании Полтавской городской думы открыть сельскохозяйственный институт (№ 2), о крупном пожертвовании в 228 тыс. руб. на Московский народный университет имени А.Л. Шанявского (№ 21), об открытии в Петербурге частных высших курсов имени П.Ф. Лесгафта (№ 29). Подобная информационная политика газеты свидетельствовала о подготовке к следующей фазе активности в крае в деле открытия своего вуза.

9 июня 1911 г. в статье-передовице А. Власов написал о необходимости открыть в Вильно частные высшие курсы сельского хозяйства. Он утверждал, что на это учреждение деньги дадут все землевладельцы, а также земства шести губерний. Помогать курсам должны также общества сельского хозяйства, а городская дума Вильно может выделить землю под фольварок, поскольку все понимают, что «...без хорошей сельскохозяйственной науки теперь ничего не сделаешь. Земледелие такая хитрая вещь, что с каждым годом делается все хитрей, люди все придумывают лучшие и лучшие способы, и нет, чтобы этому научиться» [Наша Ніва, 1911, № 23, с. 289]. Расчет автора статьи на проявление частной инициативы основывался на бурном развитии частных учреждений высшего образования в империи.

Так, в 1905 г. в империи было 14 частных вузов, но к началу Первой мировой войны, по подсчетам современных российских исследователей, их количество увеличилось как минимум в четыре раза. Среди них были очень авторитетные учреждения - Психоневрологический институт в Петербурге, Народный университет имени А.Л. Шанявского в Москве, высшие женские курсы во всех городах, где были открыты университеты. К 1915 г. в негосударственном секторе высшего образования обучалось более 50 \% студентов, и их число постоянно росло [Колчинский и др., 2018, с. 63, 65].

Более того, к этому времени на белорусских землях тоже был открыт частный вуз. Так, в 1910 г. в Витебске по инициативе членов Витебской губернской ученой архивной комиссии было основано отделение Московского археологического института, где велась подготовка работников архивов и археологов ${ }^{150}$. Витебская губернская ученая архивная комиссия представляла собой научное историческое общество, а среди его основателей и членов были видные «западноруссы» либерального толка: А.П. Сапунов, Е.Р. Романов, Е.Ф. Карский ${ }^{151}$, однако большинство членов общества составляли чиновники губернского аппарата не белорусского происхождения [Шимукович, 2020, с. 130]. Институт в Витебске не участвовал в продвижении белорусского национального проекта в том формате, как его представляли издатели «Нашей Нивы», поэтому на страницах газеты о его основании и деятельности мы не нашли ни одного информационного материала. Инициатива А. Власова не нашла поддержки, частные высшие сельскохозяйственные курсы в Вильно открыты не были.

Как отмечает российский историк А.Е. Иванов, к 1910 г. правительство озаботилось вопросами планирования развития высшего образования в империи, что было вызвано социально-экономическим развитием и возросшей потребностью в квалифицированных кадрах [Иванов, 1991, с. 181]. 16 июня 1911 г. в статье-передовице вновь говорится об открытии университета в Вильно. Как отмечает автор, в газетах пишут, что: «...постановлено открыть университет для обучения на докторов в Ростове-на-Дону, горный институт в Екатеринбурге, высшие школы сельского хозяйства в Воронеже и Самаре, а про университет для нас в Вильно не слышно». По мнению автора статьи, это происхо-

\footnotetext{
${ }^{150}$ Национальный исторический архив Беларуси (далее НИАБ). Ф. 2771. Оп. 1. Д. 160. Л. $2-8$ об.

${ }^{151}$ Там же. Д. 153. Л. 1-3.
} 
дит из-за всяких Замысловских (фамилия депутата уже становится нарицательной), в то же время многие «ученые люди» в России искренне хотят, чтобы скорее открылся университет в Беларуси, они рады, что «...большое белорусское старославянское племя пробуждается от мертвого сна» [Наша Ніва, 1911, № 24, с. 305]. В статье отмечается, что даже председатель Академии наук, великий князь Константин Константинович является сторонником университета в Вильно, и в этом же выпуске в рубрике «Со всех сторон» была размещена информация о том, что совет профессоров Академии наук высказался за открытие университета в Вильно и что в высших кругах столицы имеются сторонники данного предприятия [Наша Ніва, 1911, № 24, с. 335].

Спустя полгода, в декабре, в редакционной статье А. Власов с разочарованием отмечал, что за прошедший 1911 г. постановлено открыть несколько специализированных высших школ в городах России, а об университете в Вильно никакой информации нет. Вина за это лежит, по мнению автора, на «правых», которые подозревают «польскую интригу» [Наша Ніва, 1911, № 49, с. 626]. В этом же году в Минске городская дума совместно с губернским земством, исходя из политических и практических соображений, просила правительство открыть медицинский факультет (был учтен недавний положительный опыт основания университета в Саратове), надеясь позже добиться открытия и остальных факультетов. Прошение города осталось без положительного ответа. «Наша Нива» об этой инициативе тоже не сообщала [Пічэта, 2014, с. 223-224].

В 1912 г. виленское общество и городские власти решили воспользоваться юбилеем династии и просить учредить университет «в память 300-летия Дома Романовых». Городская комиссия по народному образованию впервые озвучила данную инициативу в январе, а в ноябре в газете сообщалось, что город готов выделить на университет 1 млн руб. и 20 десятин земли. Однако на фоне Ростова-на-Дону, городская дума которого выделяла на открытие университета 2 млн руб., эта сумма выглядела недостаточной [Наша Ніва, 1912, № 1, с. 3-4; № 48, с. 3].

Новый период активности в деле открытия вузов на белорусских землях пришелся на 1913 г. В «Нашей Ниве» было опубликовано 16 информационных материалов об открытии вузов в крае, и это больше, чем за все предшествующие годы издания газеты (см. рис. 2). Именно в 1913 г. обострилась конкуренция трех главных городов края Вильно, Минска и Витебска - за потенциальное право основать университет на своей территории. Одновременно газета сообщала и о других вариантах учреждения вузов, поскольку открытие классического университета оказалось невероятно тяжелым для реализации проектом (см. таблицу).

Обсуждение в газете «Наша Нива» наиболее актуального типа вуза для западных губерний Discussion in the newspaper «Nasha Niva» of the most relevant type of university for the western provinces

\begin{tabular}{|l|c|c|c|c|c|c|c|c|c|}
\hline \multicolumn{1}{|c|}{ Тип вуза } & $1906-1907$ & 1908 & 1909 & 1910 & 1911 & 1912 & 1913 & 1914 & 1915 \\
\hline $\begin{array}{l}\text { Университет (в Вильно, } \\
\text { Минске или Витебске) }\end{array}$ & - & 3 & 2 & - & 3 & 2 & 10 & 1 & - \\
\hline $\begin{array}{l}\text { Сельскохозяйственный } \\
\text { институт }\end{array}$ & - & 1 & - & - & 1 & - & 3 & 3 & - \\
\hline $\begin{array}{l}\text { Коммерческий } \\
\text { институт (в Минске) }\end{array}$ & - & - & - & - & - & - & 2 & - & - \\
\hline $\begin{array}{l}\text { Духовная православная } \\
\text { академия (в Вильно) }\end{array}$ & - & - & - & - & - & - & 3 & 2 & - \\
\hline $\begin{array}{l}\text { Политехнический } \\
\text { институт }\end{array}$ & - & 1 & - & - & - & - & - & - & - \\
\hline
\end{tabular}

Так, после отказа в открытии медицинского факультета минские предприниматели ходатайствовали об открытии коммерческого института. Проект, по сведениям из газет, 
обещали поддержать в Министерстве торговли [Наша Ніва, 1913, № 3, с. 3; № 5, с. 3]. Однако коммерческий институт не был поддержан минским губернатором, который считал, что он «совершенно не нужен для лиц русского происхождения, имеющих беспрепятственный доступ во все существующие в империи учебные заведения <..> и будет обслуживать исключительно лиц иудейского происхождения» (цит. по [Яновский, 2011, c. 131]). В этой ситуации Минское губернское земство инициировало открытие сельскохозяйственного института, о чем «Наша Нива» писала в августе и ноябре 1913 г. Газета также отметила, что правительство запланировало в ближайшие годы открыть подобные институты на Кавказе, в Бессарабии, Ташкенте и «...в каком-либо из городов Беларуси» [Наша Ніва, 1913, № 31, с. 3; № 47, с. 3; № 48, с. 4]. Согласие Министерства просвещения на сельскохозяйственный институт в Минске было получено весной 1914 г. [Наша Ніва, 1914, № 13, с. 4], однако начавшаяся война перечеркнула и эти планы.

В январе 1913 г. Виленская городская дума обратилась к министру внутренних дел с просьбой к императору принять депутацию от Вильно, которая будет просить его открыть университет в память 300-летия царствования Дома Романовых. Но уже в марте виленский губернатор, по информации из газеты, «деликатно отказал» городу, сообщив, что депутацию в столице не ждут. В этой ситуации инициативу попробовал перехватить Витебск, который, по мнению бывшего городского головы, а на тот момент гласного П. Коссова, имел большие шансы на получение университета [Наша Ніва, 1913, № 3, с. 2; № 11, с. 3-4].

В выпуске от 12 апреля «Наша Нива» писала, что министр образования Л.А. Кассо, приняв депутацию от Витебска, третью за прошедший год из Западного края, отказал просителям, поскольку «дело об открытии университета не срочное и не скоро придет его черед». Не добившись содействия в правительстве, витебская депутация решила добиваться университета через Государственную Думу, где провела несколько встреч и заседаний, найдя поддержку у некоторых депутатов, хорошо знающих край [Наша Ніва, 1913, № 15, с. 4; № 19, с. 4].

Стоит отметить, что проекты по открытию университетов в городах империи активно поддерживали депутаты от партии конституционных демократов, в составе которой было много представителей Академического союза из числа передовой профессуры. На Учредительном съезде партии в Москве 18 октября 1905 г. была принята программа, в которой одним из основных прав граждан признавалась «свобода основания и содержания учебных заведений», а также провозглашалась «свобода частной и общественной инициативы в открытии и организации учебных заведений всех типов», «полная автономия и свобода преподавания в университетах и других высших учебных заведениях» [Колчинский и др., 2018, с. 53-55]. Однако большинство в российском парламенте было у правых партий, которые поддерживали правительство в его крайне осторожной образовательной политике.

И все же вынесение вопроса об университете в Западном крае на парламентскую трибуну заставило правительство более основательно заняться данным вопросом. По информации «Нашей Нивы», в мае 1913 г. Министерство народного просвещения запросило в городской думе Вильно информацию о том, зачем в Вильно нужен университет и какие факультеты предполагается открыть, а в июне предложило открыть по одному факультету в каждом из трех конкурирующих за университет городов. В качестве альтернативы предлагался другой вариант - Минск и Витебск должны отказаться от университета в пользу Вильно, но все города должны участвовать в финансировании вуза. В результате борьба за право открыть университет обострилась, депутации от городов снова направились в столицу [Наша Ніва, 1913, № 21, с. 3; № 23, с. 3].

В ситуации, когда правительство уже готово было сдаться в вопросе открытия университета в западных губерниях, разрушилось хрупкое единство региональных элит в проецировании своего натиска. Так, в заглавной статье в выпуске от 19 июля 1913 г. автор (скрывался под инициалами П.Х.) отмечал, что некоторые польские круги в крае выступа- 
ли против университета, у них возникло опасение, что он станет центром обрусения края. В свою очередь, активизировались православные братства Ковенской и Виленской губерний, которые «...решили вместе с “истинно русскими” людьми просить кого надо, чтоб не позволили открывать университет, а послушали их совета и открыли в Вильно православную духовную академию <...>. Если этого совета послушать, говорят они, то можно было бы убить сразу трех зайцев: притормозить ополячивание, сдержать на всякий случай белорусов и литвинов, которые могли бы использовать университет для своего “сепаратизма" и вместе с этим еще усилить на одну позицию православную веру» [Наша Ніва, 1913, № 29, с. 1]. Таким образом, перспективы открытия университета в крае снова становились неопределенными, особенно с учетом зафиксированного в 1912 г. мнения императора о том, что государству достаточно уже открытых университетов [Иванов, 1991, с. 184].

Начало 1914 г. принесло несколько оптимистических новостей в деле открытия вузов в западных губерниях. По информации «Нашей Нивы», в феврале в Государственную Думу был подан проект закона об устройстве в крае университета и сельскохозяйственного института, а в марте газета сообщила, что Синод утвердил устав православной академии в Вильно и Министерство просвещения согласилось открыть сельскохозяйственный институт в Минске [Наша Ніва, 1914, № 7, с. 3; № 13, с. 4]. Начавшаяся вскоре Первая мировая война перечеркнула надежды региональных элит, получившие реальные очертания, на формирование в западных губерниях Российской империи полноценной инфраструктуры высшего образования.

\section{Заключение}

Таким образом, можно констатировать, что газета «Наша Нива» внимательно следила за инициативами в деле открытия высших школ в крае, а ее издатели и авторы принимали активное участие в реализации некоторых из проектов, подробно освещая свою активность на страницах издания. Отметим, что устойчивое внимание «Нашей Нивы» к высшей школе сформировалось к пятому году (1911) издания газеты, когда в каждом втором ее выпуске в том либо ином виде обозначались проблемы развития высшего образования как в империи в целом, так и в западных губерниях в частности.

Информационные материалы, посвященные необходимости открытия вуза в Западном крае, представляли собой развернутые аналитические статьи, в отличие от коротких информационных сообщений о деятельности вузов за пределами края. Наибольшее число материалов на эту тему было опубликовано в 1913 г., когда перспектива открытия вуза в западных губерниях приобрела реальные очертания, до этого публикационная активность имела прямую зависимость с готовностью правительства в принципе обсуждать данную проблему.

Деятели белорусского национального движения, группировавшиеся вокруг газеты, в частности ее редактор А. Власов, были сторонниками открытия университета в Вильно, что подчеркивали в своих публикациях. Они одобрительно отзывались на страницах «Нашей Нивы» почти о всех региональных инициативах в деле основания вузов, за исключением Духовной православной академии в Вильно. При этом на страницах газеты последовательно проводилась линия на то, что высшее учебное заведение в Западном крае должно быть белорусским по своему духу, содействовать всестороннему развитию региона и национальному возрождению белорусской нации.

\section{Список литературы}

1. Замысловский Г.Г. 2013. В борьбе с ненавистниками России. М.: Институт русской цивилизации, 720.

2. Иванов А.Е. 1991. Высшая школа России в конце XIX - начале XX века. М., Академия наук СССР, 392. 
3. Колчинский Э.И. [и др.]. 2018. Мобилизация и реорганизация российской науки и образования в годы Первой мировой войны. СПб., Нестор-История, 672.

4. Национальный исторический архив Беларуси (НИАБ). Ф. 2260 (Горецкие сельскохозяйственные учебные заведения, гор. Горки Могилевской губ.). Оп. 1. Д. 296.

5. НИАБ. Ф. 2771 (Витебская ученая архивная комиссия). Оп. 1. Д. 153, 160.

6. Наша Ніва. 1912-1915. Электронный ресурс. URL: https://knihi.com/none/Nasa_Niva_zip.html. (дата обращения: 20 мая 2021).

7. Наша Ніва. 1992. Факсімільнае выданне. Вып. 1: 1906-1908 гг. Мінск, Навука i тэхніка, 560.

8. Наша Ніва. 1996. Факсімільнае выданне. Вып. 2: 1909 г. Мінск, Беларуская навука, 768.

9. Наша Ніва. 1998. Факсімільнае выданне. Вып. 3: 1910 г. Мінск, Тэхналогія, 800.

10. Наша Ніва. 2003. Факсімільнае выданне. Вып. 4: 1911 г. Мінск: Тэхналогія, 684.

11. Пілецкі В.А. 2007. Праблемы адукацыйна-выхаваўчага працэсу, школы і школьнай палітыкі на старонках «Нашай нівы» ў 1906-1908 гг. Гісторыя: праблемы выкладання, 2: 19-23.

12. Пічэта У. 2014. Пытаньне аб вышэйшай школе на Беларусі ў мінулым. ARCHE Пачатак, 9 (130): 202-226.

13. Семёнова А.В., Корсунская М.В. 2010. Контент-анализ СМИ: проблемы и опыт применения. Под ред. В.А. Мансурова. М., Институт социологии РАН, 324.

14. Стогов Д.И. 2019. «Мозг» фракции правых: член государственной думы Г.Г. Замысловский. Таврические чтения 2018. Актуальные проблемы парламентаризма: история и современность. Сборник научных статей по итогам международной научной конференции. СПб, Астерион: 124-129.

15. Стрельцов П.П. 1903. О высшем учебном заведении в Северо-Западном крае: очерк. Витебск, Губ. типо-лит., 37.

16. Терешкович П.В. 2004. Этническая история Беларуси XIX - начала XX в.: В контексте Центрально-Восточной Европы. Минск, БГУ, 223.

17. Унучак А.У. 2008. «Наша ніва» і беларускі нацыянальны рух (1906-1915 гг.). Мінск, Беларуская навука, 186.

18. Шимукович С.Ф. 2020. Региональные проекты в сфере образования на белорусских землях в XIX веке. Долгий XIX век в истории Беларуси и Восточной Европы: Исследования по Новой и Новейшей истории: сб. науч. тр. Минск, РИВШ, 4: 118-131.

19. Яновский О.А. [и др.]. 2011. Университетоведение. Минск, БГУ, 343. Электронный pecypc. URL: https:/elib.bsu.by/bitstream/123456789/38686/1/Yanovski.pdf. (дата обращения: 29 мая 2021).

\section{References}

1. Zamyslovskij G.G. 2013. V bor'be s nenavistnikami Rossii [In the fight against the haters of Russia]. M., Institut russkoj civilizacii, 720 (in Russian).

2. Ivanov A.E. 1991. Vysshaya shkola Rossii v konce XIX - nachale XX veka [Higher School of Russia in the late 19th - early 20th century]. M., Akademija Nauk SSSR, 392 (in Russian).

3. Kolchinskij Je.I. [i dr.] 2018. Mobilizacija i reorganizacija rossijskoj nauki i obrazovanija v gody Pervoj mirovoj vojny [Mobilization and reorganization of Russian science and education during the First World War]. SPb., Nestor-Istorija, 672 (in Russian).

4. Nacional'nyj istoricheskij arhiv Belarusi (NIAB) [National Historical Archive of Belarus (NHAB)]. F. 2260 (Goreckie sel'skohozyajstvennye uchebnye zavedeniya, gor. Gorki Mogilevskoj gub. [Goretsky agricultural educational institutions, gor. Gorki Mogilevskaya Gubernia.]). Op. 1. D. 296.

5. NIAB [NHAB]. F. 2771 (Vitebskaya uchenaya arhivnaya komissiya [Vitebsk Scientific Archival Commission]). Op. 1. D. 153, 160.

6. Nasha Niva. 1912-1915. Electronic resource. Available at: https://knihi.com/none/Nasa_Niva_zip.html. (accessed: 20 maja 2021) (in Belarusian). Belarusian).

7. Nasha Niva. 1992. Facsimile edition. Vol. 1: 1906-1908. Minsk, Navuka i tjehnika, 560 p. (in 
8. Nasha Niva. 1996. Facsimile edition. Vol. 2: 1909. Minsk, Belaruskaja navuka, 768 (in Belarusian).

9. Nasha Niva. 1998. Facsimile edition. Vol. 3: 1910. Minsk, Tjehnalogija, 800 (in Belarusian).

10. Nasha Niva. 2003. Facsimile edition. Vol. 4: 1911. Minsk, Tjehnalogija, 684 (in Belarusian).

11. Pilecki V.A. 2007. Prablemy adukacyjna-vyhavaŭchaga pracesu, shkoly i shkol'naj palityki na staronkah «Nashaj nivy» u $1906-1908$ gg. [Problems of the educational process, schools and school policy on the pages of «Nasha Niva» in 1906-1908]. Gistoryya: prablemy vykladannya, 2: 19-23 (in Belarusian).

12. Pichjeta U. 2014. Pytan'ne ab vyshjejshaj shkole na Belarusi ŭ minulym [The question of higher education in Belarus in the past]. ARCHE Pachatak, 9 (130): 202-226 (in Belarusian).

13. Semyonova A.V., Korsunskaya M.V. 2010. Kontent-analiz SMI: problemy i opyt primeneniya [Media content analysis: problems and application experience]. Pod red. V.A. Mansurova. M., Institut sociologii RAN, 324 (in Russian).

14. Stogov D.I. 2019. «Mozg» frakcii pravyh: chlen gosudarstvennoj dumy G.G. Zamyslovskij [The «brain» of the right faction: member of the State Duma G.G. Zamyslovsky]. Tavricheskie chtenija 2018. Aktual'nye problemy parlamentarizma: istorija i sovremennost'. Sbornik nauchnyh statej po itogam mezhdunarodnoj nauchnoj konferencii. SPb., «Asterion», 124-129 (in Russian).

15. Strel'cov P.P. 1903. O vysshem uchebnom zavedenii v Severo-Zapadnom krae: ocherk [About a higher educational institution in the North-Western Region: an essay]. Vitebsk, Gub. tipo-lit., 37 (in Russian).

16. Tereshkovich P.V. 2004. Etnicheskaya istoriya Belarusi XIX - nachala XX v.: V kontekste Central'no-Vostochnoj Evropy [Ethnic history of Belarus in the 19th - early 20th centuries: In the context of Central and Eastern Europe]. Minsk, BGU, 223 (in Russian).

17. Unuchak A.U. 2008. «Nasha niva» i belaruski nacyyanal'ny ruh (1906-1915 gg.) [«Nasha Niva» and the Belarusian national movement (1906-1915)]. Minsk, Belaruskaya navuka, 186 (in Belarusian).

18. Shymukovich S.F. 2020. Regional'nye proekty v sfere obrazovaniya na belorusskih zemlyah v XIX veke [Regional projects in the education in the Belarusian lands in the XIX century]. Dolgij XIX vek $\mathrm{v}$ istorii Belarusi i Vostochnoj Evropy: Issledovanija po Novoj i Novejshej istorii [The Long XIX century in the History of Belarus and Eastern Europe: Studies on New and Modern History] Sb. nauch. tr. Minsk, RIVSh, 4: 118-131 (in Russian).

19. Janovskij O.A. [i dr.]. 2011. Universitetovedenie [University Studies]. Minsk, BGU, 343. Electronic resource. Available at: https://elib.bsu.by/bitstream/123456789/38686/1/Yanovski.pdf. (accessed: 29 May 2021) (in Russian).

Конфликт интересов: о потенциальном конфликте интересов не сообщалось. Conflict of interest: no potential conflict of interest related to this article was reported.

\section{ИНФОРМАЦИЯ ОБ АВТОРЕ}

Шимукович Сергей Фадеевич, кандидат исторических наук, профессор кафедры проектирования образовательных систем Республиканского института высшей школы, г. Минск, Беларусь

\section{INFORMATION ABOUT THE AUTHOR}

Serguej F. Shymukovich, Doctorate in History (PhD in History), Professor of the Department of Educational Systems Design at the National Institute of Higher Education, Minsk, Belarus 